\title{
Successful closure of a rectovesical fistula after radical prostatectomy using endoscopic submucosal dissection combined with an over-the-scope clip
}

Rectovesical fistulas after prostatectomy are rare and difficult to manage, often requiring reconstructive surgery. Few cases of endoscopic treatment are currently reported with disappointing results [1]. Endoscopic submucosal dissection (ESD) of the fistula orifice combined with a clip closure has been described as effective for chronic oeso-tracheal [2,3] and rectal [4] fistulas after surgery or Crohn's disease [5]. We report here the first success of this technique, with video illustration ( $>$ Video $\mathbf{1}$ ), to treat a rectovesical fistula occurring after radical prostatectomy for adenocarcinoma.

A 70-year-old man presented with sepsis, rectal bleeding, and urine flow through the anus 3 days after a radical prostatectomy by laparotomy. The computed tomography (CT) scan showed an inflammatory fistula tract between the posterior wall of the bladder and the anterior wall of the rectum. A fistulous orifice with a 7-mm diameter was visualized on rectoscopy at $4 \mathrm{~cm}$ from the anal margin ( $\triangleright$ Fig. 1). A left colostomy was first performed because of the sepsis. A 10-mm mucosal patch surrounding the fistulous orifice was dissected using the DualKnife J (Olympus, Tokyo, Japan) followed by submucosal injection with saline solution. The necrotic cavity was washed with normal saline solution. Mucosal closure was performed with the Twin Grasper and an OVESCO 12/6t over-thescope clip (OTSC) (Ovesco Endoscopy AG, Tübingen, Germany).

We performed this procedure 9 days after prostatectomy. Urine flow through the anus has dried up. The retrograde

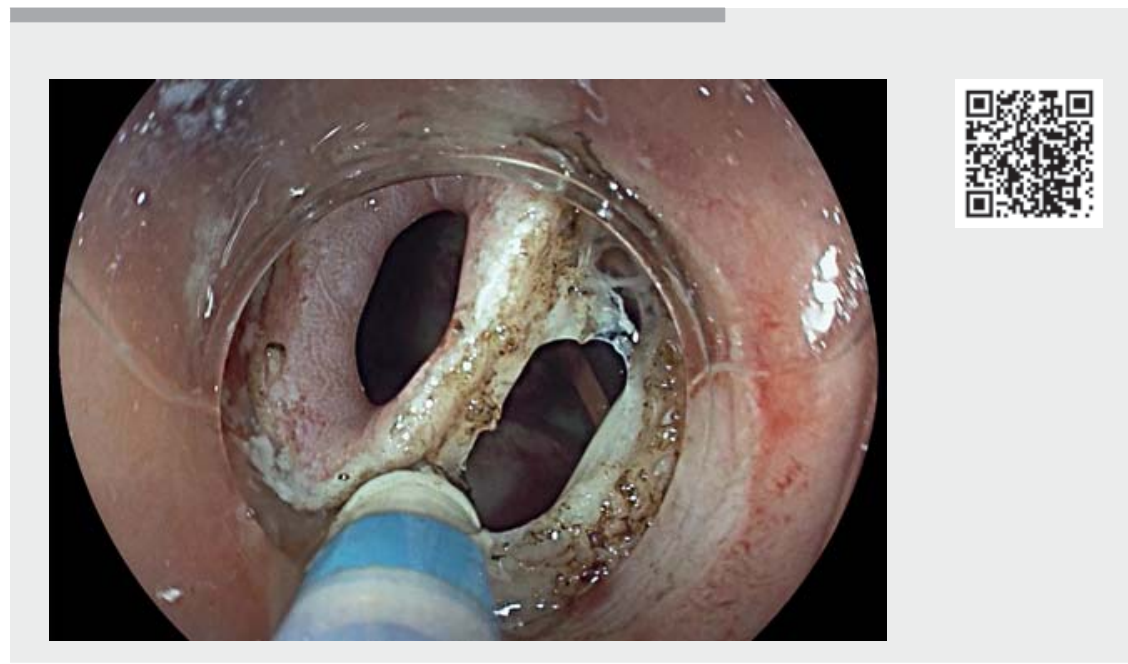

$\checkmark$ Video 1 Successful endoscopic closure of a rectovesical fistula after radical prostatectomy using endoscopic submucosal dissection combined with an over-the-scope clip.

cystography at 5 months did not identify any residual fistula tract, allowing stoma reversal. The last clinical follow-up after 6 months confirmed the complete resoIution of rectovesical fistula. ESD of the fistulous tract associated with OTSC system closure seems effective to close small digestive fistulas and might be proposed in post-operative rectovesical fistulas. A prospective study is in progress to evaluate the results.

Endoscopy_UCTN_Code_TTT_1AQ_2AG

Competing interests

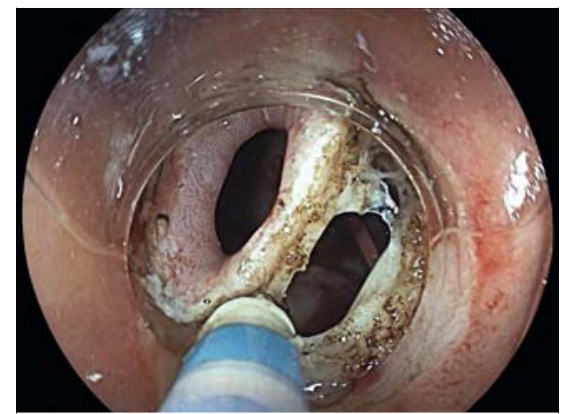

Fig. 1 Fistulous orifice with necrotic cavity between the posterior wall of the bladder and the anterior wall of the rectum at $4 \mathrm{~cm}$ from the anal margin.
The authors declare that they have no conflict of interest 
Timothee Wallenhorst ${ }^{1}$, Charlène Brochard ${ }^{1}$, Thomas Lambin ${ }^{2}$, Mael Pagenault ${ }^{1}$, Laurent Siproudhis ${ }^{1}$, Guillaume Bouguen ${ }^{1}$, Mathieu Pioche $^{2}$

1 Dept. of Endoscopy and Gastroenterology, University Hospital Centre Rennes, Rennes, France

2 Endoscopy Unit, Edouard Herriot Hospital, Lyon, France

\section{Corresponding author}

\section{Timothee Wallenhorst, MD}

Service des Maladies de l'Appareil Digestif, CHU Pontchaillou, 35033 Rennes Cedex 9, France

Fax: +33-2-99-284189

Timothee.wallenhorst@chu-rennes.fr
[1] Brodak M, Orhalmi J, Kosina J et al. Endoscopic treatment of a rectovesical fistula following radical prostatectomy by overthe-scope clip (OTSC). Wideochir Inne Tech Maloinwazyjne 2015; 10: 486-490

[2] Bertrand G, Jacques J, Rivory J et al. Deep endoscopic submucosal dissection of a refractory tracheoesophageal fistula using clip-and-line traction: a successful closure. Endoscopy 2017; 49: 1278-1280

[3] Gruner M, Heissat S, Pitiot V et al. Successful endoscopic closure of a refractory button cell tracheoesophageal fistula in a 3-year child using endoscopic submucosal dissection of the surrounding mucosa. Endoscopy 2017; 49: 212-214

[4] Barsic N, Rivory J, Monneuse O et al. Successful closure of a refractory rectal anastomotic fistula using endoscopic submucosal dissection combined with an over-the-scope clip. Endoscopy 2018; 50: 99-101

[5] Wallenhorst T, Jacques ], Bouguen $G$ et al. Successful closure of a rectal fistula of Crohn's disease using endoscopic submucosal dissection combined with an over-thescope clip. Am J Gastroenterol 2019; 114: 1416
Bibliography

Endoscopy 2021; 53: E390-E391

DOI 10.1055/a-1308-1049

ISSN 0013-726X

published online 17.12.2020

(C) 2020. Thieme. All rights reserved.

Georg Thieme Verlag KG, Rüdigerstraße 14 , 70469 Stuttgart, Germany

\section{ENDOSCOPY E-VIDEOS}

https://eref.thieme.de/e-videos

回回 Endoscopy E-Videos is a free y access online section, reporting 自被 on interesting cases and new

techniques in gastroenterological endoscopy. All papers include a high quality video and all contributions are freely accessible online.

This section has its own submission website at https://mc.manuscriptcentral.com/e-videos 